\title{
The Shifting of Halal Certification System in Indonesia: From Society-Centric to State-Centric
}

\author{
${ }^{1}$ AKIM,${ }^{2}$ NENENG KONETY, ${ }^{3}$ CHANDRA PURNAMA, ${ }^{4}$ LEEJA CITRA KORINA \\ ${ }^{1234}$ Universitas Padjadjaran, Jl. Raya Bandung-Sumedang Km.21, Indonesia \\ email: ${ }^{1}$ akim@unpad.ac.id; ${ }^{2}$ neneng.konety@unpad.ac.id; \\ ${ }^{3}$ chandra.purnama@unpad.ac.id; ${ }^{4}$ korinaleeja@gmail.com
}

\begin{abstract}
The aim of this paper is to describe the shifting of halal certification system in Indonesia, which previously tended to be society-centric towards state-centric. The needs of domestic consumers for a legally strong halal assurance system and the spread of global halal trend encourage the birth of Law Number 33 of 2014. The law makes halal certification compulsory rather than voluntary, in which the control conducted by the arrangements of LPPOM MUI is shifted to the superintendence of the Ministry of Religion through Badan Penyelenggara Jaminan Produk Halal (BPJPH) / Halal Product Guarantee Agency. This research uses a qualitative method, in which the data gathered from semi-structured interviews and studies of literature. The research result shows that the system of state-centric halal certification has more benefits than that of the societycentric system that was previously applied in Indonesia. However, it could not be proven yet since the new system has not been implemented and the supporting infrastructures have not actually been ready to operate.
\end{abstract}

Keywords: halal certification, society-centric, state-centric

\section{Introduction}

"Halal is a good value" is the most appropriate statement to define the 'halal' concept. Although initially, halal certification emerged as an alternative to protect consumers by using the teachings of Islam as its foundation (Akim, 2017), halal now is no longer limited to religious obligations amongst Muslims. Etymologically, the word 'halal' refers to the meaning of what is permissible and can be done because it is free or not bound by the provisions that prohibit it (Mudhafier \& Wibisono, 2005; Ma'luf, 1986). It rises not only as a powerful market entity but also as a world growing phenomenon for both Muslims and non-Muslims. The "halal" label on a product does not only guarantee that it is permitted to be consumed by Muslims but has also become a global symbol for quality assurance and lifestyle choices (e Halal Organization, 2010).

In line with that, halal in its full term "Halalan Thoyyiban" can be interpreted as things being allowed to be consumed in its relation to Sharia law as long as they are safe and not harmful. This definition shows that other than fulfilling the sharia requirement, halal quality also demands the product to be safe, hygienic, and wholesome. This wholesomeness (Thoyyiban) makes halal benefits not related only to religious beliefs, but also to nutrition quality, safety, hygiene, and non-contamination principle applied in the production process, making the concept of halal increasingly attractive for both Muslims and other religious followers. In addition to those two aspects, halal concept also encompass ethical consumerism values such as the fulfillment of sustainability principles, social responsibility, environmentalism, socio-economic justice, and animal welfare that increase the popularity, interest, and demand for halal certified products among non Muslim consumers to a greater extent (Edbiz Consulting, 2013).

According to the PEW Research Center, there are around 1.6 billion Muslim populations in 2010, and that number will grow to form $30 \%$ of the world's total population in 2030

Received: 2018-11-30, Revised: 2019-01-29, Accepted: 2019-05-27

Print ISSN: 0215-8175; Online ISSN: 2303-2499. DOI: http://dx.doi.org/10.29313/mimbar.v35i1.4223

Accredited $\mathbf{S 2}$ based on the decree No.10/E/KPT/2019 until 2024. Indexed by DOAJ, Sinta, Garuda, Crossreff, Dimensions 
(Edbiz Consulting, 2013). The high population growth that coincided with the growing awareness of sharia compliance amongst the Muslim consumers has led to the increased demand of halal products. In 2010, the market for halal products was estimated to have reached 2.3 trillion USD globally, where only 347 billion USD of them fulfilled (Kassim, 2010). The immense unfulfilled demand creates the growing market commitments to fulfill those needs. These are indicated by the growth rate of the global halal industry which reaches 20\% annually (Edbiz Consulting, 2013), making it one of the fastest growing consumer segments in the world.

Along with its growth rate, halal industry has expanded its range from food products only in the beginning, into a holistic halal concept which covers all commercial values such as drugs, cosmetics, health products, toiletries, medical devices. It then varies to the services field like logistics, banking, marketing, printing, electronic media, packaging, and financing. Recently, this global halal industry has expanded further into life style offerings such as halal travel packages and fashion clothing. This continuous phenomenon makes 'halal' grow to the extent that it could be considered as a trend that can provide a sense of pride and confidence for its customers (Edbiz Consulting, 2013). This does not only occur in Muslim-majority countries like Indonesia, but also in some countries with minority Muslim populations such as Thailand, South Korea, and Japan. Those Muslim-minority countries see halal as a trend that offers great opportunity for their economy, therefore developing a halal certification system on their own undoubtedly becomes one of their priority (Aminuddin, 2016; Adidaya, 2016; Numajiri, 2015). One thing that we have to be aware of is that, as more countries develop and legitimate their own halal certification system, the need to preserve halal quality standard itself (as it is known to be) becomes higher, making the whole understanding and procedures to halal certification around the world be handled more stringently (Sani and Dahlan, 2015) so does halal food demand. Although the concept of halal goes in tandem with food safety and quality, the infrastructure of both food safety and halal certification scheme is different. This paper intends to summarize briefly the food value chain scenario and describe the relationship between the food safety (hazard analysis critical control point (HACCP. Therefore, it is very important for the management of halal certification procedures to be protected by the particular authorities that are responsible for them.

Indonesia, which according to the Global I slamic Economy Indicator 2017 is the first rank country in halal food product shopping and sixth rank country in world drug and cosmetics expenditure (Nasar, 2017), regulates its halal certification procedure through a specific body of a non-governmental organization named Majelis Ulama Indonesia (MUI) called LPPOM MUI. Despite the high level of its public concern and awareness to halal products that had reached $92.2 \%$ (Sasongko and Puji, 2011), only $37 \%$ of all products sold in Indonesia has halal certificate. The Chairman of LPPOM MUI added that, out of 113 thousand registered products in Indonesia, only 41 thousand products had halal labels on it. The huge number of products that still do not possess halal labels might be caused by the voluntary principle adopted by the halal certification system in Indonesia (Abdul et al., 2013). According to Hakim (2015), the other probable reason is because of the uncertainty and the absence of specific rules about halal product assurance as the basic standard issued by the government. Instead, the rules about it are dispersed in a number of regulations that mainly discuss other particular subjects. Viverita, Kusumast usti dan Rachmawati (2017) in their study said that the reason for the lack of interest to apply for halal certification is because the standard cost set by LPPOM MUI which vary from 2.8 million rupiahs to 3.7 million rupiahs is relatively too costly for small, medium, or newly formed businesses. Because S mall and Medium Enterprises (SMEs) are under the responsibility of Ministry of Cooperatives and SMEs, LPPOM MUI does not have any obligation to directly support SMEs to obtain halal certificates.

In addition to that, Johan (2018) stated in his article that matters concerning halal certification in Indonesia intersect with several state institutions, including the Ministry of Agriculture (Directorate of Veterinary Public Health on animal-based meat and food affairs), Food and Drug Supervisory Agency (BPOM) for packaged-food, and the Ministry of Health related to the halal status of drugs and medicines - this made a single arrangement related to halal aspect done by one institution complicated and can also bring complicating results. The fact that the whole halal certification scheme in Indonesia is carried out only by the Indonesian Ulama 
Council (MUI) through LPPOM MUI, it adds to the complications. In another writing, Afroniyati (2014) highlighted the legitimacy issue of LPPOM MUI as the only institutions that provide halal certification by saying that it has become a long-standing problem on the implementation of halal certification system in Indonesia.

As a country where $86.1 \%$ of its population embrace Islam, Indonesia becomes the highest Muslim populated country in the world. This number encompasses $13 \%$ of Muslims from all corners of the world (Pew Research Center, 2015). To meet the needs of halal products for that tremendous quantity, collaboration and synergy from all related stakeholders in the country are required. Therefore, an institution or an authority that can specifically regulate the legal procedures of halal quality assurance is very crucial to fulfilling this demand in Indonesia.

This condition reinforces the importance of the government's role in protecting and ensuring halal certification under a legal umbrella, and the result is the enactment of Law No. 33 of 2014 on Halal Product Guarantee (HPG Act). This Act shifts the authority to govern halal certification which was initially under the management of a non-governmental institution (MUI) towards a government agency - Ministry of Religion through its new institution named Halal Product Guarantee Agency (BPJPH). However, if previously halal certification was registered through voluntary initiatives, with the birth of the Halal Product Guarantee Act (UU JPH) No. 33 of 2014, all the distributed products in domestic market should have halal certificates that are obtained from particular certification bodies that have been appointed by BPJPH.

Although some parties reject the "mandatory" aspect of halal-certified product brought by the HPG Act, but the rise of global halal trend has brought us to a world where halal-certified products could provide significant comparative advantage especially when they are to compete against products that are not halal-certified. This condition mostly applies in communities with diverse ethnicities, religions, and beliefs. The comparative advantage of halal certification can be briefly grouped into: (1) Authority - ensuring that the products and services provided are in accordance with the Sharia law on halal matters and creating mechanisms to monitor compliance with guidelines and standards regarding raw materials and production processes; (2) Confidence - providing assurance to Muslim consumers (and to other consumers who drop their preference for halal products); (3) Competitive advantage - expanding the scope of the market towards the readiness to meet global needs; (4) Quality - indicating that the product meets the halal requirements and the standards of strict practices of cleanliness and health; and (5) International acceptance and export market a symbol of product guarantee or identity (Ramli \& Salleh, 2013).

This article will focus on the shifting of halal certification system in Indonesia, which previously was society-centric under the arrangement of LPPOM MUI, towards the state-centric authority of the Ministry of Religion through its Halal Product Guarantee Agency (BPJPH); the changes that occur both institutionally and functionally inside the system; the reasons behind the shifting and the impact of it to all the stakeholders involved.

\section{Research Methodology}

The method used in the data collection of this research is a qualitative aim to describe the shift in the halal certification system in Indonesia. The researcher used primary data and secondary data. Primary data sources were obtained from semi-structured interviews with LPPOM MUI as the first halal certification institution that exists, which so far has made arrangements related to the halal certification process in Indonesia. In addition, the primary data sources were also obtained from BPJPH as an authorized institution to carry out the halal certification process after the enactment of Law No. 33 of 2014; Indonesia Halal Watch (IHW) and Indonesian Halal Products Foundation (YPHI) as an institution that focuses on halal issues in Indonesia. Other primary data is obtained from official documents in the form of Law No. 33 of 2014, Minister of Religious Affairs Regulations, BPJPH Vision Mission Documents, as well as the official website of LPPOM MUI and BPJPH. While the secondary data from this study came from previous research, newspaper articles, magazines, and online news.

\section{Results And Discussion}

In the Indonesian legal system, there are two phases of halal certification system 
implementation in Indonesia. The first phase is when the implementation of halal certification was society-centric by LPPOM MUI. Since LPPOM MUI is a non-governmental organization (NGO), halal certification was voluntary or optional. While the second phase is when the management of halal certification becomes state-centric, carried out by the central government. Halal certification is hence compulsory for all products circulating in Indonesia under the mandate of Law No. 33 of 2014 on Halal Product Guarantee.

\section{Halal Certification System in the Society-Centric Era in Indonesia}

The history of the halal certification in Indonesia cannot be separated from the history of the formation of LPPOM MUI as the first halal examining institution in Indonesia. The Chairman of the MUI at the time, Hasan Basri, stated that the emergence of halal certification in Indonesia was motivated by issues arising from the results of a research done by Tri Sutrisno of Brawijaya University in 1988 . The results of the study released the fact that some food products circulating among the public contained pork's DNA. This discovery shocked the Indonesian Muslim society and raised doubts about the halal-ness of rapidly-spread food products, and later turned into an issue in which the sources were not valid and credible.

As a predominantly Muslim country, this issue has become a concern of a wider public and has resulted in a drastic reduction in the sales figures of products which according to outstanding issues are thought to contain lard, and are hence haram. Instant noodles, milk, and various other food products that are not even listed in the food list examined by Tri Sutrisno were also affected. This incident certainly resulted in heavy losses to the industries producing the products. The absence of halal labels on the packaging of these products added to consumer suspicioneven though, at that time, there was no official label or symbol for a product that was halal certified.

The uproar of the issue then made the government mandate MUI as an NGO that accommodates cross-society forums, such as ulama, zuama (leaders), and Islamic scholars to conduct research related to the widespread issue of the lard-contained products. The emergence of the issue triggered an increase of public and government awareness on the importance of an institution that has the authority to conduct inspections and providing halal certification formally and continuously. In order to respond and deal with the issue, the MUI decided to form an institution that could provide official statements or halal certifications on products circulating in the public. The institution in charge of carrying out the inspection of halal products is called Assessment Institution for Food, Drug, and Cosmetics of the Indonesian Ulama Council (LPPOM MUI). $\square$ LPPOM MUI was officially established on January 6 1989, based on the Decree of the Indonesian Ulama Council. After the establishment of LPPOM MUI was technically complete, the halal certification process on food products by LPPOM MUI began to run completely around 1994. At the beginning of its establishment, MUI collaborated with the Bogor Agricultural Institute (IPB) in the form of providing laboratories and research to conduct halal certification. As the first Halal Inspection Agency in Indonesia, it can be said that LPPOM MUI is the designer of the halal certification process rules in Indonesia.

In the procedure of halal certification, LPPOM MUI involves the MUI Fatwa Commission. In this case, LPPOM MUI carries out a scientist-based task to examine the ingredients contained in a product, while the MUI Fatwa Commission as a part of the ulamabased groups will be tasked with deciding the halal nature of a product by checking its suitability with Islamic law (LPPOM MUI, 2016). In other words, the halal certification process consists of several stages, including: (1) Shipping requirements online. In this stage, the registrant will send all the required documents consisting of the company's documents or letters and an explanation of the products and materials they use. During this stage, the auditor has checked the information described in the requirements. After getting the results from the auditor, the MUI will then determine whether the auditor needs to make a visit to the production site or to only conduct a review on the materials used; (2) First-stage examination will produce two documents: (a) the Status of Halal Assurance System (SJH), which contains an assessment of products related to production activities and production materials, such as raw materials, additives, auxiliary materials) and (b) a document related to the quality of system implementation. In both inspected documents, there is an $A / B / C$ assessment category, with a minimum quality of $B$. If there 
is a $\mathrm{C}$ in at least one aspect of the assessment, the halal application will be rejected or deemed not legal. After conducting the inspection, the findings were then discussed together with the MUI Fatwa Commission; (3) the last stage is the awarding of a certificate. After a meeting between the LPPOM MUI auditors and the MUI Fatwa Commission, the Fatwa Commission will give a decision regarding whether the product is halal or not. Since the halal certification process is a collaboration between LPPOM MUI and the MUI Fatwa Commission, the halal certificates issued will be affixed by 3 signatures, namely the Chairperson of LPPOM MUI, Chair of the MUI Fatwa Commission, and General Chair of the MUI (Utama, 2018).

The ownership of the halal certificate is the right to install a halal label on the product's packaging so that the public knows that the product has been tested for its halal-ness. After the implementation of halal certification by the MUI, the Indonesian government issued regulations concerning the Halal Product Guarantee through several rules, such as Law No. 7 of 1996 on Food, Law No. 8 of 1999 on Consumer Protection, and Government Regulation No. 69 of 1999 on Food Labels and Advertisement. All regulations mentioned regarding halal certification emphasize that: (1) Provisions regarding the label and advertisement of halal status of a product could be done by the producers with the inherent responsibility attached to them. According to the rules at that time, the sponsorship of halal status was facultative or optional; (2) Since the producers are able to include halal information on their own products, specialized institutions for certifying halal products are not needed (Aminuddin, 2016).

The Law No. 7 of 1996 on Food explains that the government has the right to require fulfillment of certain food quality standards on traded food products. The requirements for food quality certification can be applied in stages based on the type of food by taking into account the readiness and needs of the food system. In addition, it is also stated that manufactured or incorporated packaged food traded inside the territory of Indonesia must include a label that contains at least: (1) product name; (2) list of ingredients used; (3) net weight; (4) the name and address of the party producing or entering food into the territory of Indonesia; (5) information about halal-ness; and (6) expiration date.
All information contained in the label and advertisement of the products must not be misleading. Therefore, any producer whose products are labeled or advertised as halal must be responsible for the truth of the statement. It was enforced by Law No. 8 of 1999 on Consumer Protection, which stated the prohibition on production and trade of goods or services that were not in accordance with the provisions of halal production, as in the "halal" statement stated in the label. Furthermore, Law No. 7 of 1996 also explained that a halal inclusion on the new food label would have a 'mandatory' status only if the food's producers or importers release a statement that the food is halal. This meant that halal labels were not compulsory, hence optional and preferential. However, if any party wanted to include halal label on the product packaging, the rules must still be accounted for. Until this stage, there was no provision that stated clearly that halal certification of products in Indonesia must be carried out by certain parties. Therefore, even though LPPOM MUI has been formed, the public could still put a halal logo on their own product packaging, as long as they felt that the ingredients used and the production process it went through did not violate the religious law regarding halal.

At the beginning, there was no question on the authority of the MUI, but when the Food Act No. 7 of 1996 came into existence, it turned out that several ministries and state officials questioned the validity (and the necessity) of halal certification granted by MUI. As for the MUI, one of the articles from Food Act No. 7 of 1996, which implicitly states that foods produced in or entering Indonesia must have a halal label on them or at least show that the products are halal, becomes the basis of the MUI's basic defense of its authority (Afroniyati, 2014).

This condition was then legally changed when the Decree of the Minister of Religious Affairs No. 518 of 2001 on Guidelines and Procedures for the Inspection and Determination of Halal Food was issued. Article 1 of this Ministerial Decree states that a halal certificate must be issued by a halal examining institution, which is not determined or explained by the Minister's Decree on who is meant by the examining institution, but only stipulated a number of criteria instead (Aminuddin, 2016). Through this ministerial decree, the LPPOM MUI became the first official halal certification and inspection agency Indonesia. MUI per se 
had previously received a mandate from the government to tackle the issue lard-contained food in Indonesia in 1988 and formed LPPOM one year later to alleviate public anxiety about the disparity between halal and haram products. It is undeniable that the MUI, along with LPPOM, has shown an effort to fulfill society needs for halal quality assurance before the issuance of legal certainty from the government on this matter.

In practice, there are numerous food producers who do not have a halal certificate from the MUI but include halal labels on their packaging. Disadvantaged, MUI thus formally determined their halal labels based on the LPPOM MUI Decree letter number SK10/Dir/ LPPOM MUI/XII/07 of 2007 concerning the halal label, which later became the official logo of the MUI's halal. The logo was previously only (halal) written in Arabic script, became the inscription in the middle of the circle surrounded by the words 'Indonesian Ulama Council' as shown below (LPPOM MUI, 2018).

The halal certification process as seen in figure 1 shows that halal-related issues are entirely under the responsibility of MUI, which is a religious society institution outside of the government. This sole authority of MUI is then delegated to the two bodies under it, the first body is LPPOM MUI and the second is Komisi Fatwa MUI. But in the end, MUI eventually acts as the only institution that has the capability to issue halal certification in Indonesia (Al-Asyhar, 2003). The position of the government during this time is a passive party: as a user, similar to the position held by ordinary people. As the entire process (starting from registration, inspection, to the issuance of certificates) is carried out by MUI as an institution of religious society, the government is not at all involved. This is what is meant by 'society-centric', where all activities, authorities and responsibilities reside in the society or the general public through institutions. The legitimacy of certificates issued is limited to those who admit it, bearing in mind the nature of societycentricism per se. In addition, it also results in the halal certification being voluntary, instead of compulsory, in which limits the sanction of every violation.

\section{Halal Certification System in the Era of State-Centric in Indonesia}

Even though more than 80 percent of the total 262.79 million people are Muslim, Indonesia is not an Islamic country. As a result, the state is not obliged to handle technical issues related to certain religious teachings, such as halal and haram (Aminuddin, 2016). The ratification of Law No. 33 of 2014 on Halal Product Guarantee (HPG Law) became the milestone of change, which regulates that all products that enter, circulate, and traded inside the territory of Indonesia must be halalcertified. In order to achieve these targets, the government will be directly responsible for administering halal product guarantees. Various reactions, both for and against such an act, coming from opposing parties made this law continue to be debated for a decade until it was finally enacted. If the law was successfully implemented, it would make Indonesia the first country in the world to require halal certification for every product in its market.

Since the beginning of the issuance of

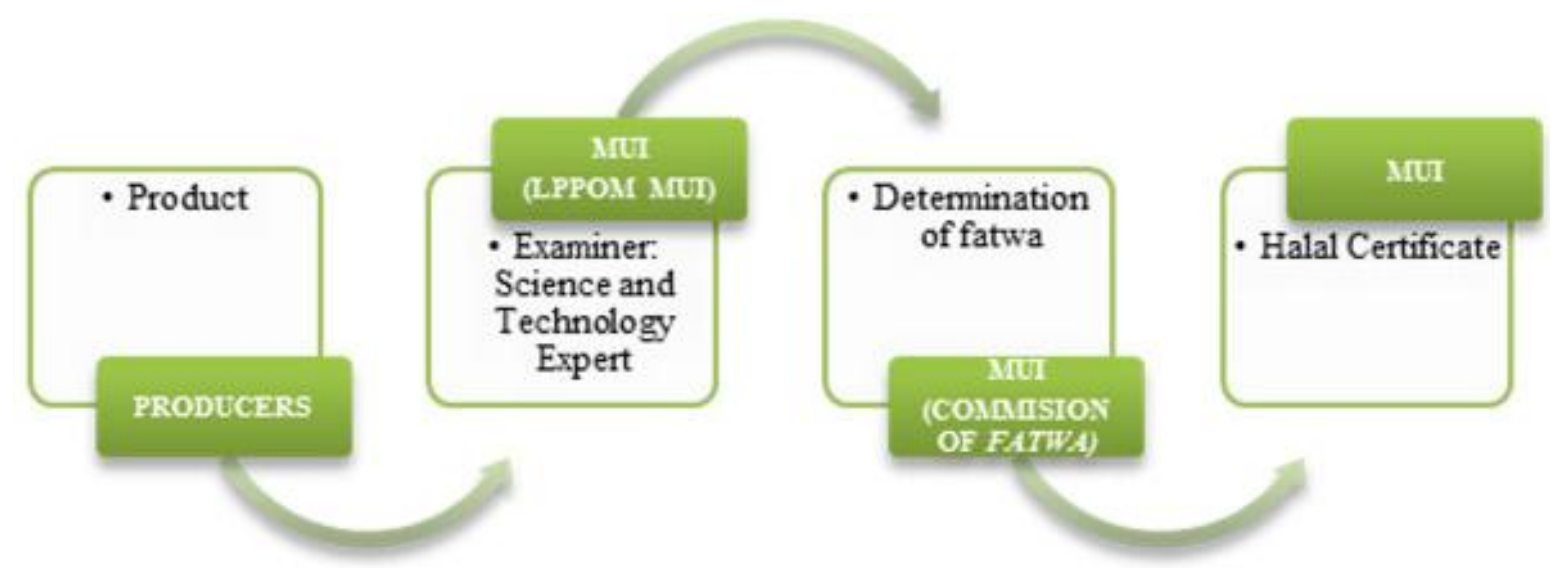

Figure 1. The Process of Halal Certification in the Era of Society-Centric in Indonesia 
the MUI's halal certification in 1989, there have been several problems, especially regarding the authority and legitimacy of the MUI in publishing halal certification. This happened because there are no clear legal rules regarding the mention of MUI as a legal institution to provide halal certification. The problems faced are increasingly diverse after the application of the Halal Product Guarantee Bill (HPG Bill) from the Ministry of Religious Affairs to the House of Representative of the Republic of Indonesia (DPR RI) was issued. The draft proposed that the authority to issue halal certification needed to be taken over from the MUI to the Ministry of Religious Affairs (Afroniyati, 2014), since the roles of both institutions-National Agency of Drug and Food Control (BPOM) and Ministry of Health-were considered to be overlapping. In the HPG Bill, several main points are explained, as in Article 20 paragraph 1 that the Minister of Religious Affairs is obliged to conduct an examination of the products being applied for or permits to obtain halal certification. It is also reinforced in paragraph 3 that the Minister can appoint a halal examining institution. Likewise, Article 30 confirms that halal certificates are obtained from the Minister of Religious Affairs as a representation of the government.

The submission of the HPG Bill also reaps the pros and cons from several parties. The biggest cons came from various parties who felt that the presence of the HPG Bill revoked the authority of MUI in matters of halal certification. Besides, the Bill considered the government taking over the system that had been pioneered from the ground by the MUI. On the other hand, the pros emphasized undeniable weaknesses of MUI: weak in the eyes of the law due to the lack of legal regulations that state the legal capacity of MUI as the only institution authorized to provide halal certification on products in Indonesia.

The HPG Law, which later became Law No. 33 of 2014 on Halal Product Assurance, regulates the Halal Product Guarantee including food, beverages, drugs, cosmetics, chemical products, biological products, genetically engineered products, and goods used or utilized by the public. Halal Product Guarantee or abbreviated as HPG constitutes a form of legal guarantee of the halal-ness of a product, proven by the ownership of a halal certificate. For the implementation of the halal guarantee, the government established the Halal Product Guarantee Agency (BPJPH) under the Minister of Religious Affairs Act
No. 42 of 2016. The Indonesian Ulama Council (MUI) which was originally the single institution that handles the halal certification affairs in Indonesia has now changed its function, becoming a partner of BPJPH whose task is to facilitate the discussion of ulama, zuama, and Muslim scholars in determining halal fatwas for halal certification which will be issued by the government.

Article 6 of Law No. 33 of 2014 explains that in the implementation of the halal guarantee system, BPJPH holds the authority to formulate and establish HPG policies; determine whether the norms, standards, procedures or criteria are applied to HPG; it is also the authority of BPJPH to issue and revoke Halal Certificates and Halal Labels on consumer products or uses; register halal certificates in foreign products; socializing, educating, and publishing halal products; accreditation of Halal Inspection Institution (LPH); supervise HPG; conduct halal auditor development; and cooperating with domestic and foreign institutions in the field of HPG implementation (eg. related ministries/institutions, LPH, and MUI). The collaboration between BPJPH and LPH is carried out by audits and/or product testing, while cooperation between BPJPH and MUI will be carried out in the form of halal auditor certification; stipulation of product halal (fatwa); and LPH accreditation.

The adoption of the Law of Halal Product Guarantee legally marks the change in the governance of halal certification in Indonesia which was previously only carried out by LPPOM MUI to the hands of several parties under the coordination of BPJPH. In the halal certification system before the JPH Law, companies that apply for halal certificate must fill out the registration form and attend the halal guarantee system training beforehand. After the financing has been repaid and the examination of document adequacy has been completed, LPPOM MUI will carry out checks or audits to the company. If a lab analysis is needed, the product will be analyzed in the lab before the results are submitted to the MUI fatwa commission meeting to determine its halal status. If the MUI fatwa commission meeting says that the product is halal, then the halal certificate will be issued by the MUI.

Based on the JPH Law, the procedure for obtaining a halal certificate will involve $\mathrm{BPJPH}, \mathrm{LPH}$ and MUI. First of all, business actors must submit a complete document as well as a written application for a halal certificate to BPJPH. Business actors can 
also choose LPH based on the preference or proximity of their business location to the $\mathrm{LPH}$ and BPJPH. BPJPH then determines LPH who has the right to test the halal of the product within a maximum period of 5 working days from the date the complete application document is submitted. The next stage is checking the halal production process by halal auditors at the business location. If there are ingredients or materials still vague in its halal nature, further testing will be carried out in the laboratory. After obtaining the results, LPH will give them to BPJPH, which will be submitted to the MUI. MUI is then responsible in determining their legal status in the MUI fatwa commission session. The halal fatwa session was held no more than 30 working days after the MUI received the documents from BPJPH. Once the decision made, the final document regarding the establishment of halal status of products is then signed by the MUI to become the basis for $\mathrm{BPJPH}$ issuing halal certificates, which is done within 7 working days after MUI's final decision. The issuance of the halal certificate must then be published by BPJPH, thus its use can be monitored by the public.

The halal certification process as seen in figure 2 that halal matters are the responsibility and authority of the government. For that being said, the government takes a dominant role in the entire halal certification process. Other institutions outside the government are still given a role in the halal certification process, but their role is limited to providing assistance outside the government domain. In halal certification, the government acts as an active actor in the entire process from the registration to the issuance of halal certificates. This is referred to as a state centric halal certification process; a condition in which responsibility, authority, and activities are carried out or controlled by the government. While other non government actors are in a passive position since the authority they have is granted by the government or in this case, BPJPH as the official organ of the Ministry of Religious Affairs. For example, the LPH authority, as a non-government institution that checks the halal-ness of a particular product, is basically a government authority. Before becoming a $\mathrm{LPH}$, an institution must submit an application, which needs to be approved by the government. Likewise, the MUI has a role in giving sharia legal considerations to the halal certification process. However, the final decision about halal as proven by the halal certificate remains the authority of BPJPH as the official state institution.

\section{The Impact of Halal Certification System Shifting in Indonesia}

Before the enactment of the Law No. 33 of 2014 on Halal Product Guarantee, the halal certification system for all industries was carried out by a single institution, namely LPPOM MUI. The Law facilitates coordination of various stakeholders to improve the efficiency and effectiveness of halal certification governance as seen in table 1 , which will later be obliged to all products marketed in Indonesia. Even though halal certificates are issued by the government, the one that conducts examination is $\mathrm{LPH}$, instead of the Ministry of Religious Affairs or BPJPH. As the Law gives LPH a significant role in halal certification process, it indirectly fosters new job opportunities in the community. It also allows a system of checks and balances between BPJPH as policy makers, LPH and MUI as executors, and the society as the policy supervisors through submitting reports and

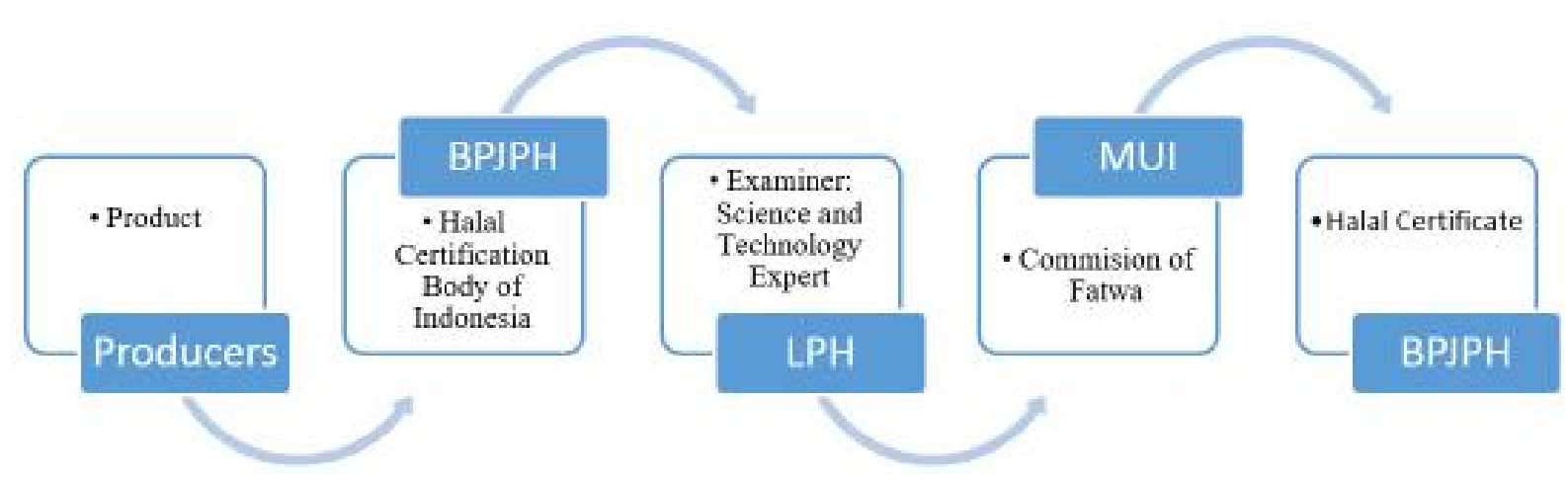

Figure 2. The Process of Halal Certification in the Era of State-Centric in Indonesia 
complaints to BPJPH should any violation is found. In addition, this system also avoids accumulation in one particular stage that will hamper the overall certification process.

As for the costs, the halal certification system managed by non-government institutions tended to be costlier than the one managed by the government institution. The government has the ability to set aside a budget or build cooperation with other related stakeholders. It is stated in Article 44 of the HPG Law that the cost of halal certification is charged to the business actors submitting a halal certificate. However, if the business actor is classified as a micro and small business, the cost can be borne by another party-government, in this regard.

From the perspective of international cooperation, the shifting of Indonesia's halal certification management system from the society to the hands of the government clarifies the structure of international cooperation that might occur. It happens because the pattern of relations that originally occurred between actors from different levels, such as NonGovernment to Government, has become more equal; Government to Government. Thus, the negotiation and communication process can be relatively more effective. This is evident in the IMT-GT (Indonesia, Malaysia, Thailand Growth-Triangle) trilateral cooperation, in which there is specific cooperation in halal industry. Before BPJPH was established, Indonesia could not actively participate in such specific cooperation. This is due to the limited capacity of nongovernmental institutions to discuss on specific matters related to the duties of other ministries or agencies. In this regard, BPJPH becomes the face of Indonesia in halal affairs to play an active role in the IMT-GT.

This system shift also affects the governance of halal certification of products originating from abroad. The prior halal certification system required submission of re-certification of each type of product from abroad, although the product's originating country already had recognition cooperation from MUI. However, the current halal certification system under the Law No. 33 of 2014 allows the form of HPG development and/or cooperation in mutual recognition of halal certificates between countries. This new system allows foreign businesses to have their halal products marketed in Indonesia without recertification-as long as the halal certificates they own are issued by foreign halal institutions that have been registered by BPJPH (before they are marketed in Indonesia).

The entire system has been made in such a way as to ensure effective, efficient, and accountable governance of halal certification that is expected to meet the needs of halal guarantees for all products in Indonesian market. However, the Government Regulation which will regulate the implementation of Halal Product Guarantee has not yet come out. BPJPH, which was officially established on October 11, is now in the stage of building infrastructure. The infrastructure certainly includes government regulations that contain detailed guidelines for implementing the new Halal Product Guarantee system. To date, the Government Regulation has been completed and communicated with related bodies, such as the Drug and Food Inspection Agency, Ministry of Health, Ministry of Industry, Ministry of Trade, etc. The relevant agencies and institutions have contributed ideas and improvements to the Government Regulation and are now in the final stages of being sent to the President. In this case, the approval of the relevant ministers will also be needed.

Until now, even though BPJPH has been formed, the submission or extension of the halal certificate is still carried out by following the procedures that apply before the HPG Law. Ideally, the MUI will still carry out the existing arrangements in the field of halal certification up to the establishment of BPJPH. However, even after the establishment of BPJPH, there have not been visible changes in the national halal certification system. This is certainly the biggest challenge for implementing halal guarantee obligations for products that are circulated and traded in domestic markets, which under the HPG Law must take effect on October 17, 2019.

The Head of BPJPH, Prof. Sukoso, has realized this challenge regarding the halal certification system according to Law No. 33 of 2014. It is said that there has not been comprehensive socialization of existing system updates. Most of the socialization is actually carried out by private parties who indeed felt the need to prepare themselves. Since the target of the HPG Law are wide, from micro, small and medium enterprises (MSMEs) until large companies, BPJPH have to think of solutions to strengthen and prepare MSMEs to be ready to compete. Along with the obligatory halal guarantee, Indonesian domestic market, including MSMEs, must 
be ready to face the global market. This challenge must be solved together so that MSMEs would not marginalized by the global market and foreign halal products would not dominate the domestic market. To be successful, all respective stakeholders should realize the potential of Indonesian MSMEs as a force that can break down the global halal market.

It should be noted that the shift of halal certification management system in Indonesia occurred not because the previous system was unprofessional. The prior system has gone well, except that due to the dynamism

Table 1

Comparison of the Halal Society-Centric with State-Centric Certification System

\begin{tabular}{|c|c|c|}
\hline Criteria & Society-Centric & State-Centric \\
\hline Stakeholder & Indonesian Ulama Council (MUI) & The Ministry of Religious Affairs \\
\hline Implementing agency & $\begin{array}{l}\text { Assessment Institution for } \\
\text { Food, Drug, and Cosmetics of } \\
\text { the Indonesian Ulama Council } \\
\text { (LPPOM MUI) }\end{array}$ & $\begin{array}{l}\text { Halal Product Guarantee Agency } \\
\text { (BPJPH) }\end{array}$ \\
\hline The nature of halal certification & Voluntary (facultative) & Compulsory \\
\hline Certification process & $\begin{array}{l}\text { Centered on a single institution } \\
\text { (MUI) }\end{array}$ & $\begin{array}{l}\text { Dominant state institutions, } \\
\text { but some authorities are } \\
\text { distributed to private institutions, } \\
\text { universities, etc. }\end{array}$ \\
\hline Related parties & $\begin{array}{l}\text { MUI (LPPOM MUI, MUI Fatwa } \\
\text { Commission) }\end{array}$ & $\begin{array}{l}\mathrm{BPJPH}, \mathrm{MUI}, \mathrm{LPH}, \text { private } \\
\text { institutions and universities }\end{array}$ \\
\hline Newly formed institution(s) & - & Halal Inspection Institution (LPH) \\
\hline Strengths & $\begin{array}{l}\text { a. The system is already steady; } \\
\text { b. Halal certification is voluntary. }\end{array}$ & $\begin{array}{l}\text { a. Less costly; } \\
\text { b. The choice of LPH is more } \\
\text { vary; } \\
\text { c. Facilitating the presence of } \\
\text { LPH in the private sector, } \\
\text { universities, and other } \\
\text { community organizations; } \\
\text { d. Facilitating interstate } \\
\text { collaboration; } \\
\text { e. A mandatory halal assurance } \\
\text { on products circulating in } \\
\text { society under the supervision } \\
\text { of the government reinforces } \\
\text { the presence of the state in } \\
\text { the protection of consumer } \\
\text { rights; } \\
\text { f. Increase public awareness } \\
\text { of halal global emerging } \\
\text { trends, thereby stimulating } \\
\text { the competitiveness of local } \\
\text { products in the global market. }\end{array}$ \\
\hline Weaknesses & $\begin{array}{l}\text { a. There is only one choice } \\
\text { in filing halal certification } \\
\text { throughout Indonesia; } \\
\text { b. It is difficult to collaborate } \\
\text { between countries; } \\
\text { c. More expensive; } \\
\text { d. There is no legal umbrella that } \\
\text { covers the regulation of halal } \\
\text { certification for MUI; } \\
\text { e. Its nature which is centered on } \\
\text { the scope of the MUI alone has } \\
\text { resulted in the vulnerability of } \\
\text { transparency issues. }\end{array}$ & $\begin{array}{l}\text { a. The system has not operated } \\
\text { yet; } \\
\text { b. Socialization on mandatory } \\
\text { halal certification has not } \\
\text { been maximized. }\end{array}$ \\
\hline
\end{tabular}


of globalization and the demands of the global market, Indonesia must be more proactive in taking advantage of opportunities. Indonesia, which until 2016 is still the most populous Muslim country in the world, requires a more proportional amount of human resources facility in terms of halal guarantee services, and a halal certification system under the mandate of Law No. 33 of 2014 seems to be ready to accommodate this.

\section{Conclusions}

Based on the explanation above, it can be seen that Indonesia is currently experiencing a period of shifts on its halal certification system, which was initially society-centric under the control of the MUI through its LPPOM towards a state-centric system where the Government through the Ministry of Religious Affairs holds the authority through BPJPH as the responsible institution. With this system shift, Indonesia can witness the strengths and weaknesses of each system. However, although the halal certification system in Indonesia can be stronger under the authority of the state, it has not been equipped with legal facilities and required infrastructure such as the relevant Government Regulations that discuss the technical implementation of the Law of Halal Product Guarantee. This indicates that although the design of the new halal certification system is already an ideal, but it is not yet ready to be implemented. Thus, it is still uncertain for us to say that Indonesia's halal certification system is moving in a better direction.

\section{References}

Abdul, M. et al. (2013) 'Indonesian Small Medium Enterprises ( SMEs) and Perceptions on Halal Food Certification', African Journal Business Management, 7(16), pp. 1492-1500. doi: 10.5897/ AJBM11.2926.

Adidaya, Y. A. (2016) Halal in Japan: History, Issues, and Problems - The Effect of the 'Halal Boom' Phenomenon on Japanese Society and Industry. University of Oslo.

Afroniyati, L. (2014) 'Analisis Ekonomi Politik Sertifikasi Halal oleh Majelis Ulama Indonesia', Jurnal Kebijakan dan Administrasi Publik, 18(1 Mei 2014 ISSN 0852-9213).

Akim (2017) Proteksi Perdagangan Nontarif Indonesia Terhadap Impor Paha Ayam Dari Amerika Serikat Melalui Sertifikasi Halal
(2000-2015). Universitas Padjadjaran.

Akim et al. (2018) 'Contribution of Higher Education Institutions in Supporting Indonesian Halal Product Guarantee Policy 2019', in 2nd International Conference on Social and Political Development (ICOSOP 2017). Paris: Atlantis Press, pp. 321-326. Available at: https://www. atlantis-press. com/proceedings/icosop-17/25892103.

Al-Asyhar, T. (2003) Bahaya Makanan Haram Bagi Kesehatan Jasmani dan Kesucian Rohani. 1st edn. Jakarta: Al Mawardi Prima.

Aminuddin, M. Z. (2016) 'Sertifikasi Produk Halal: Studi Perbandingan Indonesia dan Thailand', Shahih, 1(1), pp. 2839. Available at: http://ejournal. iainsurakarta.ac.id/index.php/shahih/ article/viewFile/52/44.

E-Halal Organization (2010) Your Ultimate Guide to The World of Halal Food.

Edbiz Consulting (2013) Global Islamic Finance Report 2013. London.

Hakim, A. L. (2015) 'Dissecting the Contents of Law of Indonesia on Halal Product Assurance', Indonesia Law Review, 5(1), pp. 88-103.

Johan, E. (2018) 'New Challenges in ASEAN Regional Market : International Trade Framework on Halal Standard', Jurnal Dinamika Hukum, 18(1), pp. 93-102.

Kassim, A. (2010) 'The Global Market Potential of Halal', in Proceedings of International Conference \& Expo on Halal Industry. Lahore.

LPPOM MUI (2016) Indonesia Halal Directory 2014-2015. Bogor: Global Halal Center LPPOM MUI.

LPPOM MUI (2018) Panduan Umum Sistem Jaminan Halal LPPOM MUI. Jakarta: LPPOM MUI.

Ma'luf, L. (1986) Al-Munjid Lighah wa AlA'lam. Beirut: Dar Al-Masyariq.

Mudhafier, F. and Wibisono, H. A. F. (2005) Makanan Halal Kebutuhan Umat dan Kepentingan Pengusaha. 2nd edn. Jakarta: Zakia Press.

Nasar, M. F. (2017) Negara dan Sertifikasi Halal IndonesiaNegara dan Sertifikasi Halal Indonesia. Available at: https:// kemenag.go.id/berita/read/505898/ negara-dan-sertifikasi-halal-indonesia (Accessed: 10 April 2018).

Numajiri, M. (2015) A Religious Sociological Study of Halal Boom in Japan: Intercultural Understanding Brought by the Religious Taboo. Otemon Gakuin University.

Peraturan Menteri Agama No. 42 Tahun 2016 (2016) Tentang Organisasi dan Tata Kerja 
Kementerian Agama. Available at: https:// bimasislam.kemenag.go.id/uploads/files/ PMA_42_2016_ORTAKER.PDF.

Peraturan Pemerintah No.69 Tahun 1999 (1999) Tentang Label dan Iklan Pangan.

Pew Research Center (2015) 10 Countries With the Largest Muslim Populations, 2010 and 2050. Available at: http://www.pewforum. org/2015/04/02/muslims/pf_15-0402_projectionstables74/ (Accessed: 11 May 2018).

Ramli, N. and Salleh, H. M. (2013) 'Do We Need Halal Certification, Research, and Training', in Hasyim, Y. Z. Y. (ed.) Halal: All That You Need to Know. Kuala Lumpur: Institut Terjemahan \& Buku Malaysia Bernhad, pp. 6-12.

Sani, N. A. and Dahlan, H. A. (2015) 'Current Trend for Food Safety and Halal Measures Current Trend for Food Safety and Halal Measures', in ASEAN Community Conference. Bangi: Researchgate.

Sasongko, A. and Puji, S. T. (2011) 50 Persen Produk Halal Impor Berasal dari China. Available at: https://www. republika.co.id/berita/dunia-islam/ fatwa/12/01/13/157117-50-persenproduk-halal-impor-berasal-dari-china (Accessed: 21 November 2018).

Undang-Undang No. 33 Tahun 2014 (2014) Tentang Jaminan Produk Halal. Indonesia. Available at: http://www.dpr.go.id/ dokjdih/document/uu/1615.pdf.

Undang-Undang No. 7 Tahun 1996 (1996) Tentang Pangan. Available at: http:// standarpangan.pom.go.id/dokumen/ peraturan/lain-Iain/UU_Nomor_18_ Tahun_2012_Tentang_Pangan.pdf.

Undang-Undang No. 8 Tahun 1999 (1999) Tentang Perlindungan Konsumen.

Utama, H. (2018) 'Wawancara 29 Juni 2018'. Bogor: LPPOM MUI.

Viverita, Kusumastusti, R. D. and Rachmawati, R. (2017) 'Motives and Challenges of Small Businesses for Halal Certification : The Case of Indonesia', World Journal of Social Sciences, 7(1), pp. 136-146. 